\title{
Professor Pietro Motta
}

\section{(1942-2002)}

With great sadness we have to announce that our Editorial Board member, Professor Pietro Motta, Chairman of the Department of Human Anatomy of the University of Rome 'La Sapienza', passed away on June 19, 2002. We have lost one of the most prominent scientists in reproductive biology, a passionate electron microscopist, very active author and bood editor, and a great friend.

Professor Motta will be missed, but his outstanding personality and numerous scientific contributions will be a source of memory and inspiration for his friends and collaborators.

H.-W. Denker, Essen A. English, Atlanta, Ga.

\section{KARGER}

๑ำ 2002 S. Karger AG, Basel

Fax +41613061234 